\title{
TEAM EFFECTIVENESS IN SOFTWARE DEVELOPMENT: THE ROLE OF PERSONALITY AND WORK FACTORS
}

\author{
Auksė ENDRIULAITIENĖ®i), Lina CIRTAUTIENĖ ${ }^{*}$ \\ Vytautas Magnus University, Kaunas, Lithuania \\ Received 26 May 2020; accepted 13 January 2021
}

\begin{abstract}
Globalization and dynamic economic conditions have exponentially increased the use of virtual work in organizations. Effectiveness in software development teams, therefore, is now a relevant issue in business, psychology or other fields. Despite the uniqueness of software development teams and their work conditions, their effectiveness has not been sufficiently researched to clearly determine how it relates to personality traits, work challenges and the virtualization level. To expand the understanding of the mechanisms that influence team effectiveness in software development, an ecological framework is selected. The purpose of this study is to explore the relationship between personality traits, work factors and team effectiveness within the context of software development teams. Methodology: The exploratory study was conducted in international software development companies operating in Lithuania. Forty-five software development teams $(\mathrm{N}=142)$ filled in the Team task performance scale, Hexaco-PI-R questionnaire and rated perceived work challenges and team virtualization level. The statistical analysis was conducted with SPSS. This survey is an initial stage of a larger project. Findings: Personality traits Conscientiousness and Extraversion relate to team effectiveness. In software development teams the most prevalent work challenges were time zone differences, lack of information when working on a project, and lack of a clear purpose. Lack of information and poor foreign language skills negatively affect team effectiveness. A higher virtualization level is associated with more frequent work challenges (culture and foreign language challenges, time zone differences) and team performance.
\end{abstract}

Keywords: software development, team, virtualization level, IT sector, effectiveness, personality traits.

JEL Classification: O330.

\section{Introduction}

Globalization and dynamic economic conditions have exponentially increased the use of virtual work in organizations (Bógdał-Brzezińska, 2020). Consequently, the traditional physical work environment becomes less common (Constant et al., 1996), whereas different virtual work forms take lead instead (Raghuram et al., 2019). Companies gain competitive advantage in business as well as in the labor market by building global collaboration (Thuong, 2019), adopting technological advances, and applying the informative-communicative (ICT) appliances in daily practices (Grenier \& Metes, 1995; Miles \& Snow, 1986, 1992). Organizations, work groups, and single employees apply ICT to daily work practice and move their work to the cyberspace. The number of virtually working people (Lipnack \& Stamps, 1997; McDonough et al., 2001) and virtual organizations (Carmel \& Agarwal, 2001;
McDonough et al., 2001) is predicted to be on the increase in the future. These factors make software development teams and their performance efficiency a relevant issue to business, psychology, and other fields.

Innovation and ITC's usage in organizations have altered the nature of work (Morrison-Smith \& Ruiz, 2020). Labor processes have been transformed: work can be geographically dispersed, and new work-like activities are created (Raghuram et al., 2019; Webster \& Randle, 2016). However, virtual work is predominant only among some types of organizations, mostly in the software development (Information Technology, IT) sector. Software development companies are specific in that they operate in a unique organizational environment, in which the form of working virtually with no direct contact seems to be efficient. Such companies are often global, intercultural, inter-organizational, and self-managing, whereas their teams carry out related tasks and share responsibility for

*Corresponding author. E-mail: lina.cirtautiene@vdu.lt 
the result but organize work virtually. The high expectations for IT solutions raise the requirements for the quality of work (Brownell, 2006; Xiang et al., 2013). Clients demand excellent performance from software developers, who are expected to generate new ideas and make creative decisions in a short time (Colomo-Palacios et al., 2014; El-Sofany et al., 2014). Since software developers are compelled to accept changes, their ability to adapt is crucial. Therefore, employees have to find ways to manage unique work factors and personal capacities in order to be effective.

Software development teams have specific work conditions. Aforementioned differences between virtual, collocated and global teams stem from their contextual environment. According to the ecological framework, internal environment, external environment, and boundaries all have an immediate impact on a virtual team's effectiveness (Lankes et al., 2005). The ecological framework stresses the critical role of the environment through a reciprocal interdependency between internal processes and the external environment, and it has been previously used for virtual team studies (Shachaf \& Hara, 2002). It consists of components that are critical to virtual team effectiveness: microsystem (as personality traits, communication pattern in team), mesosystem (as lack of information when working on a common project, lack of clear team goals), macrosystem (as virtuality level, time zones, crosscultural team), exosystem (as software developing), and macrosystem (general environment). There has been little work done in examining the challenges faced by virtual teams (Morrison-Smith \& Ruiz, 2020).

The effectiveness of a project team leads to work quality and productivity (Norhanim, 2019). Despite that, the effectiveness of teams has not been investigated enough, which leaves the importance of personality traits, work challenges and virtualization level unclear. Most studies investigate collocated, non-spread team performance (Higgs \& Dulewicz, 2016; Ewen et al., 2013; Stelmokiené, 2012), with direct communication (emigrants, students) (Felker, 2012; Stelmokienè, 2012) or with temporary virtual communication (Yilmaz \& Peña, 2014). The influence of personality traits on effectiveness has been studied only in specific cultures (Horwitz et al., 2003; Paik et al., 2000), but not globally. Furthermore, the correlates of virtual IT team effectiveness have been analyzed mostly in literature review articles (Engle et al., 2015; MorrisonSmith \& Ruiz, 2020), and in the managerial or technological context (Dobre \& Xhafa, 2014; Chatzipetrou et al., 2015; Jokūbauskiené, 2013; Lazzarotti et al., 2015). Since a psychological approach is usually lacking, it is difficult to establish how previous results might be used for the explanation of software development team effectiveness.

Research linking personality traits and work factors to effective performance within the context of IT teams has been limited. Thus, this paper aims to explore software development teams and their effectiveness taking into account such psychological factors as personality traits and perceived work challenges.

\section{Team effectiveness in software development}

The effectiveness of software development teams is widely investigated (Colomo-Palacios et al., 2014; Dingsøyr \& Dybå, 2012; El-Sofany et al., 2014; Moe \& Dingsøyr, 2008). A high-performing team is recognized as one of the essential conditions for running a successful organization. Team members work together towards specific goals and assume some responsibility for team success (Moe \& Dingsøyr, 2008). However, teamwork is more often explored from a managerial perspective, focusing on one type of a specific task (e.g., decision-making, idea generation) or comparing the performance between some tasks (Colomo-Palacios et al., 2014; El-Sofany et al., 2014). Gained information validates organizational factors as actual environment meaningful for team effectiveness (El-Sofany et al., 2014). In software development teams, technological innovation and technical skills are a priority, with insufficient emphasis placed on the social component and socio-emotional competences (Dingsøyr \& Dybå, 2012). This narrow perspective of the conducted research opens a major gap in the study of software development teams.

According to some scholars, software development team effectiveness refers to the team's ability to accomplish its assigned tasks (Shea \& Guzzo, 1987). However, such a definition is more in line with the concept of productivity. Team effectiveness differs from team productivity. Psychological factors, such as team interaction and satisfaction with cooperation in team, also contribute to team effectiveness, while team productivity may be conditioned by the general environment (Moe \& Dingsøyr, 2008). Thus, team effectiveness does not only encompass performance but also such elements as human and cooperative aspects (Dingsøyr \& Dybå, 2012), socioemotional consequences of group action, and member satisfaction and attraction to the group (Sundstrom et al., 1990). A number of frameworks have been composed to bring together the most important components of teamwork (Dingsøyr \& Dybå, 2012; Salas et al., 2005), however, their evaluation and implementation in practice is difficult (Moe \& Dingsøyr, 2008; Dingsøyr \& Dybå, 2012). This paper relies on several studies (Hoegl \& Gemuenden, 2001; Gladstein, 1984; Denison et al., 1996) in which team success is conceptualized by such common components as performance and satisfaction. According to Hoegl's team effectiveness model, teamwork quality is described as team performance and personal success (Hoegl \& Gemuenden, 2001). In the cross-functional team effectiveness model (Denison et al., 1996), team effectiveness is explained through growth satisfaction and overall effectiveness. In the group effectiveness model (Gladstein, 1984), team effectiveness is measured by performance and satisfaction. We define team effectiveness as task performance and member satisfaction with teamwork.

Each member contributes to team efficiency. Personality traits and communication skills are critical components of team effectiveness (Hackman \& Oldham, 1980; Shea \& Guzzo, 1987; Sundstrom et al., 1990). Contextual 
surrounding has an immediate impact on the virtual team effectiveness as well (Shachaf et al., 2005). To be adaptable in uncertain situations, self-managed software development teams must maintain a sufficient level of autonomy (Dingsøyr \& Dybå, 2012). Effectiveness in a team is possible only by supporting technological processes with social components of the team (Dingsøyr \& Dybå, 2012). Therefore, the effectiveness of the team should be analyzed with a variety of dimensions, both at the team and at the individual level.

To study the effectiveness of software developers more closely, personality and work factors must be considered. It remains unclear which work factors contribute to software developer team effectiveness.

\subsection{The role of personality in software development team effectiveness}

According to personality traits theories (Allport et al., 2003), traits represent the basic tendencies we use to adapt to our environment thus they can be linked to individual and team effectiveness. Personality traits and communication style have a combined effect on the productivity of the organization (Norhanim, 2019; Solaja et al., 2016). Language fluency, good communication skills, trust, accessibility and independence correlate with successful communication. Personality traits influence employees' beliefs about perceived virtual team communication and performance effectiveness (Jacques et al., 2009). On the individual level, personality traits are important for individual performance (Cruz et al., 2015). In the context of technology supported virtual team collaboration, personality traits have also been argued to affect an individual's disposition to trust and willingness to collaborate (Brown et al., 2004). Team composition is important not only for individual but also for team efficiency in a virtual team (Norhanim, 2019). Personality styles may contribute to project team overall success (White, 1984; De Vreede et al., 2012).

Over the last decade, scholars have questioned the capacity of the five-factor personality model to describe the personality structure. A six- factor personality model was proposed and found to be superior to the five-factor model in terms of all three - the psychological, the theoreti$\mathrm{cal}$, and the practical - aspects. In HEXACO personality model, personality traits can be broadly organized into six dimensions as extraversion, honesty-humility, emotionality, agreeableness, conscientiousness, and openness to experience (Ashton \& Lee, 2009). Therefore, this study uses the latter model.

Extraversion correlates positively with individual performance in jobs involving social interaction in local teams (Barrick \& Mount, 1991) and is the key personality correlate with individual impact on group performance (Barry \& Stewart, 1997). There is disagreement whether extraversion facilitates positive or negative results for a team. In some studies, extraversion seems advantageous to a team's operations, enhances the participation of team members and team satisfaction, as well as the promotion of team performance (Barrick \& Mount, 1991; Hogan et al., 1994). Furthermore, positive emotional interaction and the establishment of a sense of trust between team members promote cooperation satisfaction (Joinson, 2002). On the other hand, some studies show lower extraversion to positively affect communication and thus virtual team performance by facilitating or hindering the exchange of information among group members (Balthazard et al., 2004). High levels of extraversion and higher variations in extraversion between team members lead to less constructive and more passive/defensive interaction styles within teams (Balthazard et al., 2004; O'Neill et al., 2014). Introverted individuals perceived themselves as having more influence and their teams as more cohesive and communicative than did more extraverted individuals (Dineen, 2005). Therefore, low levels of extraversion within a team can facilitate team interaction and effectiveness.

Team member honesty - humility contributes to team effectiveness (Chiu et al., 2016), as it helps the members be more open-minded, acknowledge their limitations and mistakes (Owens et al., 2011, notice the strengths of others, create a more accurate view of reality (Owens et al., 2011), as well as be willing to learn from others, be more open to their colleagues' new ideas and advice or gaining information, and has positive implications to teamwork satisfaction and performance. Humility helps acknowledge the areas of inexperience and to foster learning and adaptation in a team (Weick, 2001). Thus, high levels of honesty within a team will facilitate team's interaction and team effectiveness.

Individuals scoring high in agreeableness more readily share knowledge, which results in higher levels of interpersonal trust (Matzler et al., 2006). In teams, cooperative, tolerant and helpful persons are welcome. Such individuals tend to prevent conflicts (Digman \& Inouye, 1986), and have coordinative skills to solve them (Graziano et al., 1996). In this regard, if team members are highly agreeable, the establishment of a sense of trust and relationships that facilitate team cohesion will be created. Agreeableness also has a positive impact on the perceived usefulness of a virtual team (Devaraj et al., 2008). Despite that, agreeableness was not found to be a predictor of job performance (Judge et al., 1999). We assume that if team members are highly agreeable it will foster team effectiveness.

Individuals that exhibit openness to experience are receptive to their surroundings in various domains, interested in unusual ideas or people, like to experience new things, and tend to come up with many different ideas. Personality traits like openness have a positive impact on the perceived usefulness of a technology (Devaraj et al., 2008). Openness to experience and positive communication with others facilitate a sense of trust between team members, as well as team effectiveness (Barrick \& Mount, 1991). Seeking to share and absorb experiences and opinions of others, as well as a willingness to facilitate the operations of the team result in a high degree of team effectiveness (Barrick \& Mount, 1991). 
Individuals with very high emotionality feel intense anxiety in every-day life, need emotional support from others, and are more empathic. An emotional individual is tense, worries more than others, and is moody. In stressful situations, an emotional person finds it difficult to control their impulses (Bruck \& Allen, 2003). Emotionality corelates with self-reported stress and perceived frustration with workload (Kirkman et al., 2002). Emotionality creates tension in team communication and may lead to negative team outcomes in communication, satisfaction and performance. Thus, low levels of emotionality within a team facilitate team effectiveness.

A conscientious person is highly achievement-oriented and has a strong sense of purpose, obligation, and persistence, which helps them perform better (Furumo et al., 2009). In a team, a conscientious individual prefers to work alone when they know the solution for the situation and expects their efforts to be recognized by others. Conscientious persons show enhanced performance in vigilance tasks (Kirkman et al., 2002). Conscientiousness may be positively related to team performance because of the careful and thorough accomplishment of tasks, aided by a strong sense of purpose, obligation and persistence.

Psychological factors have been mistakenly ignored as an element that does not impact IT team effectiveness (Chujfi \& Meinel, 2015). Recent studies insufficiently assess the importance of personality traits in software developer teams. Most studies investigate specific personality traits (Eissa et al., 2012; Owens et al., 2013; Chiu et al., 2016), personality traits are analyzed in a managerial sample (Balthazard et al., 2004; Chiu et al., 2016), in nonvirtual team context (Chiu et al., 2016), and without taking cross-cultural challenges into account (O'Neill et al., 2014). Researchers are more interested in the obvious differences between IT team members - they assess their demographic characteristics (age, gender, educational differences), but fail to answer what personality traits and work factors are meaningful for team effectiveness and teamwork satisfaction.

Based on the previous literature review, we assume that higher conscientiousness, openness to experience, agreeableness, humility, and lower extraversion and emotionality of software team members are positively related to team effectiveness.

\subsection{Work factors as perceived challenges in software development teams}

While the IT sector is the most innovative and most likely to evolve, it has its own specific work conditions and challenges. Global virtual work is beneficial to its employees the work is positively evaluated as complex, creating learning opportunities and thus promoting innovation, satisfaction and engagement (Nurmi \& Hinds, 2016). Highly competent, talented teams are often trusted to make decisions on their own. Intercultural virtual teams can develop new ideas that can improve innovation and creativity, combining different team member opinions (Zakaria et al., 2004). Facilitating virtual team collaboration and understanding their needs can boost team creativity, and provide competitive and organizational advantage.

Otherwise, virtual environment creates challenges. Continuous change brings uncertainty, tension and stress (Naik \& Bisht, 2014). Software development teams are characterized by cultural diversity, geographical spread, electronic dependence, and structural dynamism (often changing team members) (Gibson \& Gibbs, 2006) termed as "global distance" (Noll et al., 2010). A systematic literature review identified global dispersion dimensions geographical dimension (as different time zones), work dispersion (as lack of clear purpose, failure to work on a virtual basis), cultural dispersion (as different cultures), and organizational dispersion (as lack of information when working on a common project/product, conflicts between team members) (Morrison-Smith \& Ruiz, 2020; Nguyen-Duc et al., 2015). A combination of work factors gives rise to differences which may also pose some substantial challenges (Jarvenpaa et al., 1999).

Work factors are analyzed as conditions that are important for team effectiveness (Morrison-Smith \& Ruiz, 2020; Verburg et al., 2013). Specific work factors, such as cultural diversity and a shared unique knowledge, increase innovation and creativity but reduce fluent coordination and cause misunderstandings. Virtuality and work challenges, such as time zone differences, lack of information, lack of clear team goals, conflicts in team, and different cultures, are meaningful work factors for performance. Even though work challenges that virtual IT workers face might affect the effectiveness of the performance, they continue to be poorly examined (El-Sofany et al., 2014). Hence, it becomes vitally important to analyze the impact of work factors on efficient team performance.

We assume that more frequently experienced work challenges will be related to lower team performance.

Virtualization level. Companies increasingly use virtual solutions in teams (Maznevski \& Chudoba, 2000). The degree of virtuality is defined and measured as the amount, frequency, and quality of electronically mediated communication (Niederman \& Beise, 1999; Verburg et al., 2013). Virtual teams consist of two or more persons who collaborate interactively to achieve common goals, while at least one of the team members works at a different location, even at a different time zone, thus their communication and coordination is mainly based on electronic communication media (phone, fax, e-mail, video conference, etc.) (Hertel et al., 2005). Virtuality resides on a continuum from low to high (Raghuram et al., 2019). Therefore, use of electronic communication is meaningful to explore team virtualization level and its consequences (Axtell et al., 2004).

Team virtualization level is one of the work factors that might affect team performance (Wang \& Hsu, 2012). Virtualization can improve job satisfaction and organizational efficiency (Kommeren \& Parviainen 2007; Sooraj \& Mohapatra, 2008), and save organizational resources (Smite et al., 2010). Members of a virtual team can easily 
communicate and work together, readily meet the needs of different clients, participate in global projects, and contact colleagues abroad. Best employees may be recruited without needing to relocate. Virtual teams can sustain the flexibility of their organizations.

However, distant communication raises the challenge for the virtually working IT specialists to communicate their ideas clearly and solve work problems effectively in a cyberspace (Gassmann \& Von Zedtwitz, 2003). Research results show that virtual teams are characterized by large staff turnover and difficulty in implementing IT projects on time (Colomo-Palacios et al., 2014; Li et al., 2016). Working in a virtual team requires more work and is usually less productive (Colomo-Palacios et al., 2014). Few empirical studies analyze the features of a long-term virtual work team, thus the levels of effectiveness of virtual teams remains a controversial topic.

Comparing performance of traditional and virtual teams, the level of satisfaction is lower for virtual compared to traditional teams (May \& Carter, 2001), whereas distributed teams made worse decisions than the control groups (Dennis \& Wixon, 2001-2002). We assume higher virtualization level to be associated with more frequent work challenges and to negatively corelate with software developer team performance. Other work challenges may be analyzed through global dispersion dimensions - geographic dimension, work dispersion, cultural dispersion and organizational dispersion (Nguyen-Duc et al., 2015).

Geographical dimension is defined as a physical separation and may be evaluated through different time zones (Nguyen-Duc et al., 2014). Due to the geographical distance between the team members, they communicate in a virtual manner (Martins \& Schilpzand, 2011). Time difference is evaluated as a frequent boundary in virtual teams (El-Sofany et al., 2014). Such distance factors are tightly coupled with social and emotional factors and correlate with a set of challenges that greatly affect virtual teams (Morrison-Smith \& Ruiz, 2020). Time differences can have a negative impact on team productivity, and distribution of activities has a direct impact on the overall project outcomes (Avritzer et al., 2010). Remote and rare direct communication complicate effective collaboration (Gassmann \& Von Zedtwitz, 2003). According to Pettersen (2020), employees who are close geographically are also close to the social structure in which other colleagues reside, and work problems may be solved more easily. Geographical distance together with time, cultural and language differences may create boundaries for the effectiveness of software developer teams (El-Sofany et al., 2014; Morrison-Smith \& Ruiz, 2020).

Work dispersion is described as differences in tasks, work environment, tools and development practices, and may be evaluated through the lack of a clear purpose and failure to work on a virtual basis (Nguyen-Duc et al., 2015). Software development teams often lack clear hierarchies and structures (Collins et al., 2017), which reflects on their working model. The more virtual the team is, the more independent work is desirable. This may decrease team members' efforts to reach the goal. Lack of a clear objective for projects is the most common problem (ElSofany et al., 2014) that makes work in a virtual environment more challenging.

Cultural dispersion refers to the cultural, linguistic and background differences among team members, and may be assessed as cultural differences or difficulties in speaking foreign languages (Nguyen-Duc et al., 2014). Cultural diversity within a team can cause confusion among members and negatively affect mutual understanding (Collins et al., 2014; Norhanim, 2019). Cultural differences together with different values and attitudes serve as a filter for environmental perception (Norhanim, 2019). Cross-cultural virtual teams are less cohesive, their members have less confidence in each other (Gibson \& Gibbs, 2006), it is difficult for them to communicate and effectively coordinate work processes (Hinds \& Mortensen, 2005).

In order to be effective, precise and consistent in information exchange and intensive cooperation, fluent language skills are significant for trust and cultural sensitivity in teams (Henry \& Hartzler, 1998). Poor foreign language skills may become a boundary to fluent communication and be evaluated as challenging in virtual teams (El-Sofany et al., 2014).

Organizational dispersion encompasses differences in objectives, development strategies, organizational structure and communication, and may be assessed as lack of information when working on a common project or conflicts between team members (Nguyen-Duc et al., 2015).

Lack of information while working on a common project and lack of clear team goals can significantly reduce the effectiveness of virtual IT teams. Perceived (subjective) distance as impression of how far others are may have a greater effect on relationship outcomes (Morrison-Smith \& Ruiz, 2020). In virtual teams, the performance success is more dependent on the value of the available information and knowledge, therefore, the exchange of information and smooth communication is more significant than in collocated teams (Collins et al., 2014). If team members are not ready to share their knowledge to help others, effectiveness decreases significantly.

Misunderstandings among team members, task and relationship conflicts due to their differences are more likely to emerge in virtual than in collocated teams. Distant teams lack physical meetings, which are important for establishing trust and getting acquainted with fellow team members (Morrison-Smith \& Ruiz, 2020; Pettersen, 2020). Teams face communication, coordination and control challenges (Avritzer et al., 2010; Casey \& Richardson 2009; García-Crespo et al., 2010). Teams working with outsourcing tasks have been found to lack important insights into the social structure to which their work problems and colleagues belonged (Pettersen, 2020). Relationship conflicts are frequent in virtual teams, and they reduce satisfaction and commitment toward the team, increase stress and anxiety, and limit information processing abilities of the team members (Jehn, 1995, 1997; Simons \& Peterson, 2000). 
Virtual IT team often suffers from cultural differences, interpersonal problems, communication misunderstandings, and stressful environments (Collins et al., 2014; Morrison-Smith \& Ruiz, 2020). However, which of them are more frequent in software developers' teams remains unclear. Although research is segmental, it can be assumed that more frequent challenges negatively affect the performance of the virtual team.

The purpose of this study is to explore the relationship between personality traits, work factors (work challenges and virtualization level) and team effectiveness within the context of software development teams.

Thus, the following hypotheses were developed:

Hypothesis 1: Higher humility, agreeableness, conscientiousness, openness to experience, and lower extraversion and emotionality are positively related to software developers' team effectiveness.

Hypothesis 2: More frequently experienced work challenges are related to lower software developers' team performance.

Hypothesis 3: A higher virtualization level is associated with more frequent work challenges and negatively corelates with software developer team performance.

\section{Methodology}

\subsection{Sample and procedure}

The participants of this study were software developers working in teams. Forty-five teams with 142 employees from 8 organizations participated in the study. The average team size was 8 members (from 6 to 10), the mean work experience was 5 years (the mean -5 years, SD = 9 years). The average work experience at current company was 3.21 years, $\mathrm{SD}=7.53$. 85 percent of the respondents were working with colleagues from other countries. The mean age of the subjects was 28 years (range from 20 to 56 years). The study involved 107 men and 35 women $(\mathrm{N}=142)$. Seventy-nine percent of the subjects had a higher education.

Data were collected using convenience sampling. For each team, all members received an introductory letter and a link to an online questionnaire. Each potential participant was asked to complete a 20 minute online survey. The survey was conducted in Lithuanian. The questionnaire was introduced as a set of questions regarding virtual team peculiarities. Research instruments were chosen based on previous studies (Huang et al., 2002; Ashton \& Lee, 2009), covered areas targeted in the present study (Wang \& Hsu, 2012; Ashton \& Lee, 2009), and were applied in the software development team sample (Wang et al., 2012).

\subsection{Instruments}

Team performance effectiveness (TPE) was measured by the Team task performance scale (Tjosvold, 1988; Huang et al., 2002), consisting of two sub-scales (performance subscale and satisfaction with team cooperation subscale). The results of individual sub-scales are used separately in the calculations, and the total score of the team performance is not calculated (Wang \& Hsu, 2012). The questionnaire consists of 10 items, measured by the 5 points in the Likert scale: very often, quite often, sometimes, rarely, never. The theoretical model is confirmed empirically (Hsu et al., 2007). Other researchers use this questionnaire to assess team effectiveness in IT sector (Wang, 2010).

Performance subscale (Cronbach $\alpha=.86$ ) (Wang et al., 2012) contains six items concerning task efficiency (including outcomes, quality, innovation, rate of progress, and other measures of success). Higher scores indicate a higher level of task performance. For example, "The team reached the target well".

Satisfaction subscale (Cronbach $\alpha=.90$ ) (Wang et al., 2012) contains four items concerning employee satisfaction with their teamwork (including satisfaction with team cooperation or perception of their interactions, and the degree of optimism for future cooperation). Higher scores indicate a higher satisfaction with teamwork. For example, "I felt very happy in the process of participating in the team".

Personality traits were assessed by Hexaco-PI-R questionnaire (Ashton \& Lee, 2009) that is designed to explore the six-factor personality model. The questionnaire consists of 60 items, measured in terms of Honesty - Humility (Cronbach $\alpha=.60$ ), Emotionality (Cronbach $\alpha=.78$ ), Extraversion (Cronbach $\alpha=.80$ ), Agreeableness (Cronbach $\alpha=.75$ ), Conscientiousness (Cronbach $\alpha=.75$ ) and Openness to Experience (Cronbach $\alpha=.69$ ). All items in the questionnaire were rated on 1 (disagree) to 5 (agree) Likert scale. The theoretical model of six personality traits is confirmed empirically (Lee et al., 2005), in different cultures (Ion et al., 2017).

Work challenges. Respondents answered questions about perceived work challenges. Work challenges were chosen based on a literature review. Seven frequent challenges (lack of clear purpose, lack of information while working on a common project, conflicts in team, cultural differences, poor foreign language skills, failure to work on a virtual basis, different time zones) were included as items in the survey. Higher scores indicate a higher level of work challenges within teams. The statements are measured on the 5 point Likert scale.

Team virtualization level was assessed by Team virtualization level questionnaire (Wang \& Hsu, 2012). Using five items, team members were asked to indicate the team virtualization level. The five questions encompassed three dimensions: the frequency of virtual tools use (example item "Please indicate the extent to which your team uses IT tools in their communication as a percentage of the tools used"), informational value (example item "The team members can access the database in order to retrieve the information they need at any time"), synchrony (example item "During the operation process, in addition to traditional face-to-face communication, the team members also use other types of IT tools as communication tools"). Higher scores indicate a higher level of virtualization within teams. The statements were measured on the 5 
point Likert scale (Cronbach $\alpha=.92$ ). Studies have shown that the scale is applied in the information technology sector to assess the degree of virtuality, and the theoretical model has been validated empirically (Wang \& Hsu, 2012; Wang, 2010).

Socio-demographic information. Respondents provided basic socio-demographic information (gender, age, education, work experience, working in a cross-cultural team).

\section{Results}

\subsection{Personality traits in software development teams}

Personality traits and team effectiveness. First of all, data analysis was done by using descriptive statistics (mean, standard deviation for components and questions in the questionnaire), correlation test and regression analysis to test hypothesis of the relationship between personality traits and team effectiveness (SPSS.23 was used). The Pearson zero-order correlations between personality traits and team effectiveness were analyzed (see Table 1).

Table 1. Means, Standard Deviations and Correlations for measures used in the study at the individual level

\begin{tabular}{|l|c|c|c|c|}
\hline \multicolumn{1}{|c|}{ Variables } & Means & SD & $\begin{array}{c}\text { Perfor- } \\
\text { mance } \\
\text { (TE) }\end{array}$ & $\begin{array}{c}\text { Satis- } \\
\text { faction } \\
\text { (TE) }\end{array}$ \\
\hline 1. Performance (TE) & 3.99 & .71 & 1 & $.248^{* *}$ \\
\hline 2. Satisfaction (TE) & 4.30 & .78 & $.248^{\star *}$ & - \\
\hline 3. Honesty-Humility & 3.56 & .49 & $.332^{\star *}$ & .065 \\
\hline 4. Emotionality & 3.00 & .70 & .182 & $.198^{\star}$ \\
\hline 5. Extraversion & 3.12 & .68 & .079 & .182 \\
\hline 6. Agreeableness & 3.33 & .60 & $-.296^{\star *}$ & $.282^{\star *}$ \\
\hline 7. Conscientiousness & 3.78 & .58 & $.210^{\star}$ & .057 \\
\hline $\begin{array}{l}\text { 8. Openness to } \\
\text { Experience }\end{array}$ & 3.38 & .60 & $.237^{\star}$ & .065 \\
\hline
\end{tabular}

Note: ${ }^{*} \mathrm{p}<.05,{ }^{*} \mathrm{p}<.01$.

Software developers' personality traits are important to team performance at the individual level. Personality traits, as Honesty-Humility $(\mathrm{r}=.332, \mathrm{p}<.01)$, Emotionality $(\mathrm{r}=$ $.198, \mathrm{p}<.05)$, Conscientiousness $(\mathrm{r}=.210, \mathrm{p}<.05)$, Openness to Experience $(r=.237, \mathrm{p}<.05)$, correlate in a significant positive direction with team effectiveness (as task efficiency in performance subscale or as employee satisfaction with their teamwork in satisfaction subscale) with the exception of Agreeableness. Positive relationships emerged between Agreeableness and Satisfaction scale $(\mathrm{r}=.282, \mathrm{p}<$ .01 ), but Agreeableness negatively correlates to Performance scale $(\mathrm{r}=-.296, \mathrm{p}<.01)$. These findings explain that while Agreeableness contributes to higher satisfaction in teamwork, it does not lead to higher productivity.

For comparison purposes at the team level, five teams with the highest and lowest performance ratings were identified. Estimates of their members' personality traits were compared by one-way analysis of variance (ANOVA) between high or low performance groups and team performance. There were no statistically significant differences between groups.

\subsection{Work factors and team effectiveness}

Main challenges of working in a software team. Frequent challenges are presented by the means of the work factors (in Table 2), where a higher average indicates a more frequent challenge. From the seven work challenges that were presented to the respondents, the most common choices were time zone differences, lack of information when working on a common project, lack of clear team goals, and different cultures.

Table 2. Distribution of reported challenges while working in software development teams

\begin{tabular}{|l|c|}
\hline \multicolumn{1}{|c|}{ Variables } & Means (Likert Scale) \\
\hline 1. Time zone differences & 3.5 \\
\hline $\begin{array}{l}\text { 2. Lack of information when working } \\
\text { on a common project/product }\end{array}$ & 2.9 \\
\hline 3. Lack of clear purpose & 2.52 \\
\hline 4. Different cultures & 2.21 \\
\hline 5. Conflicts between team members & 1.74 \\
\hline 6. Failure to work on a virtual basis & 1.65 \\
\hline 7. Do not speak foreign languages & 1.52 \\
\hline
\end{tabular}

To assess whether work challenges took effect on team performance, a one-way analysis of variance (ANOVA) was conducted on seven work challenges. Mean levels significant for team performance are presented in Table 3. In Table 3 , the ANOVA on lack of clear purpose $\mathrm{F}(16,62)=1,73$, $\mathrm{p}<0.05$ and do not speak foreign languages $\mathrm{F}(16,82)=$ $2.39, \mathrm{p}<0.01$ revealed a significant main effect for the Performance subscale. Consequently, lack of a clear goal and lack of language skills reduced employee productivity.

Table 3. ANOVA results using Performance and Satisfaction as criterion

\begin{tabular}{|c|c|c|c|c|c|}
\hline Variables & $\begin{array}{l}\text { Sum of } \\
\text { Squares }\end{array}$ & $\mathrm{df}$ & $\begin{array}{l}\text { Mean } \\
\text { Square }\end{array}$ & $\mathrm{F}$ & $\mathrm{p}$ \\
\hline & \multicolumn{5}{|c|}{ Performance subscale } \\
\hline 1. Lack of clear purpose & $\begin{array}{l}29.38 \\
87.24\end{array}$ & $\begin{array}{l}16 \\
82\end{array}$ & $\begin{array}{l}1.84 \\
1.06\end{array}$ & 1.73 & $.05^{*}$ \\
\hline \multirow[t]{2}{*}{$\begin{array}{l}\text { 2. Do not speak foreign } \\
\text { languages }\end{array}$} & 108 & $\begin{array}{l}16 \\
82\end{array}$ & $\begin{array}{l}1.36 \\
0.57\end{array}$ & 2.39 & $.01^{* *}$ \\
\hline & \multicolumn{5}{|c|}{ Satisfaction subscale } \\
\hline $\begin{array}{l}\text { 1. Lack of information } \\
\text { when working on a } \\
\text { common project }\end{array}$ & $\begin{array}{c}26.43 \\
109.34\end{array}$ & $\begin{array}{l}11 \\
87\end{array}$ & $\begin{array}{l}2.40 \\
1.26\end{array}$ & 1.91 & $.05^{\star}$ \\
\hline $\begin{array}{l}\text { 2. Conflicts between } \\
\text { team members }\end{array}$ & $\begin{array}{l}21.36 \\
54.60\end{array}$ & $\begin{array}{l}11 \\
87\end{array}$ & $\begin{array}{l}1.36 \\
.57\end{array}$ & 3.10 & $.01^{* *}$ \\
\hline 3. Different cultures & $\begin{array}{c}29.52 \\
121.64\end{array}$ & $\begin{array}{l}11 \\
87\end{array}$ & $\begin{array}{l}2.68 \\
1.40\end{array}$ & 1.92 & $.05^{\star}$ \\
\hline $\begin{array}{l}\text { 4. Do not speak foreign } \\
\text { languages }\end{array}$ & $\begin{array}{l}17.09 \\
51.36\end{array}$ & $\begin{array}{l}11 \\
87\end{array}$ & $\begin{array}{l}1.55 \\
.59\end{array}$ & 2.63 & $.01^{* *}$ \\
\hline
\end{tabular}

Note: ${ }^{\star} \mathrm{p}<.05,{ }^{* *} \mathrm{p}<.01$. 
High levels of work challenges have an effect on Satisfaction subscale (see Table 4). There was a significant effect of work challenges on team performance in Satisfaction scale at the $\mathrm{p}<.05$ level for the three conditions: lack of information when working on a common project $[\mathrm{F}(11,87)=1.91, \mathrm{p}<.05]$, conflicts between team members $[\mathrm{F}(11,87)=3.1, \mathrm{p}<.01]$, different cultures $[\mathrm{F}(11,87)=1.92, \mathrm{p}<.05]$, do not speak foreign languages $[\mathrm{F}(11,87)=2.63, \mathrm{p}<.01]$. In other words, employees' lack of language skills, cultural differences, conflicts between team members, and lack of information while working on a single project reduced employee job satisfaction in a team.

According to the results, problems that respondents encounter while working in an allocated team affect team performance at the individual level.

At the team level, five teams with the highest and lowest performance ratings were identified. Estimates of work

Table 4. ANOVA results using Performance and Satisfaction as criterion in five teams with the highest and five teams with the lowest performance ratings

\begin{tabular}{|c|c|c|c|c|c|}
\hline Variables & $\begin{array}{l}\text { Sum of } \\
\text { Squares }\end{array}$ & $\mathrm{df}$ & $\begin{array}{l}\text { Mean } \\
\text { Square }\end{array}$ & $\mathrm{F}$ & $\mathrm{p}$ \\
\hline & \multicolumn{5}{|c|}{ Performance subscale } \\
\hline $\begin{array}{l}\text { 1. Lack of clear } \\
\text { purpose }\end{array}$ & $\begin{array}{c}5.24 \\
31.00\end{array}$ & $\begin{array}{c}1 \\
31\end{array}$ & $\begin{array}{l}5.25 \\
1.00\end{array}$ & 5.25 & $.03^{*}$ \\
\hline $\begin{array}{l}\text { 2. Lack of information } \\
\text { when working on a } \\
\text { common project }\end{array}$ & $\begin{array}{c}.24 \\
43.28\end{array}$ & $\begin{array}{c}1 \\
31\end{array}$ & $\begin{array}{l}.24 \\
1.40\end{array}$ & .17 & .68 \\
\hline $\begin{array}{l}\text { 3. Conflicts between } \\
\text { team members }\end{array}$ & $\begin{array}{c}1.58 \\
21.94\end{array}$ & $\begin{array}{c}1 \\
31\end{array}$ & $\begin{array}{l}1.58 \\
.71\end{array}$ & 2.23 & .15 \\
\hline 4. Different cultures & $\begin{array}{c}2.22 \\
45.97\end{array}$ & $\begin{array}{c}1 \\
31\end{array}$ & $\begin{array}{c}2.322 \\
1.48\end{array}$ & 1.49 & .23 \\
\hline $\begin{array}{l}\text { 5. Failure to work on } \\
\text { virtual basis }\end{array}$ & $\begin{array}{c}2.68 \\
27.20\end{array}$ & $\begin{array}{c}1 \\
31 \\
\end{array}$ & $\begin{array}{c}2.68 \\
.88\end{array}$ & 3.05 & .09 \\
\hline $\begin{array}{l}\text { 6. Do not speak } \\
\text { foreign languages }\end{array}$ & $\begin{array}{c}.07 \\
12.17\end{array}$ & $\begin{array}{c}1 \\
31\end{array}$ & $\begin{array}{l}.07 \\
.39\end{array}$ & .17 & .68 \\
\hline \multirow[t]{2}{*}{$\begin{array}{l}\text { 7. Different time } \\
\text { zones }\end{array}$} & $\begin{array}{c}.01 \\
52.06\end{array}$ & $\begin{array}{c}1 \\
31\end{array}$ & $\begin{array}{l}.01 \\
1,68\end{array}$ & .01 & .96 \\
\hline & \multicolumn{5}{|c|}{ Satisfaction subscale } \\
\hline $\begin{array}{l}\text { 1. Lack of clear } \\
\text { purpose }\end{array}$ & $\begin{array}{c}7.29 \\
30.22 \\
\end{array}$ & $\begin{array}{c}1 \\
31\end{array}$ & $\begin{array}{c}7.29 \\
.98 \\
\end{array}$ & 7.48 & $.01^{* *}$ \\
\hline $\begin{array}{l}\text { 2. Lack of information } \\
\text { when working on a } \\
\text { common project }\end{array}$ & $\begin{array}{c}.99 \\
35.56\end{array}$ & $\begin{array}{c}1 \\
31\end{array}$ & $\begin{array}{c}.99 \\
1.15\end{array}$ & .86 & .36 \\
\hline $\begin{array}{l}\text { 3. Conflicts between } \\
\text { team members }\end{array}$ & $\begin{array}{c}1.21 \\
31.51\end{array}$ & $\begin{array}{c}1 \\
31\end{array}$ & $\begin{array}{l}1.21 \\
1.02\end{array}$ & 1.19 & .28 \\
\hline 4. Different cultures & $\begin{array}{c}.61 \\
58.72\end{array}$ & $\begin{array}{c}1 \\
31\end{array}$ & $\begin{array}{l}6.11 \\
1.89\end{array}$ & .32 & .57 \\
\hline $\begin{array}{l}\text { 5. Failure to work on } \\
\text { virtual basis }\end{array}$ & $\begin{array}{c}.41 \\
40.50\end{array}$ & $\begin{array}{c}1 \\
31\end{array}$ & $\begin{array}{c}.41 \\
1.31\end{array}$ & .31 & .058 \\
\hline $\begin{array}{l}\text { 6. Do not speak } \\
\text { foreign languages }\end{array}$ & $\begin{array}{c}.32 \\
25.56 \\
\end{array}$ & $\begin{array}{c}1 \\
31\end{array}$ & $\begin{array}{l}.32 \\
.82\end{array}$ & .39 & .54 \\
\hline $\begin{array}{l}\text { 7. Different time } \\
\text { zones }\end{array}$ & $\begin{array}{c}.51 \\
53.56\end{array}$ & $\begin{array}{c}1 \\
31\end{array}$ & $\begin{array}{l}.51 \\
1.73\end{array}$ & .29 & .59 \\
\hline
\end{tabular}

challenges were compared with the help of one-way analysis of variance (ANOVA) between high or low team performance groups. Statistically significant differences between groups' equality of means emerged in Lack of clear purpose in high and low Performance subscale means $\mathrm{F}(1,31)=5.25, \mathrm{p}<.05$, and in high and low Satisfaction subscale means $\mathrm{F}(1,31)=7.48, \mathrm{p}<.05$. Such results reaffirmed that the lack of clear information about the goal not only reduces job satisfaction in the team but also its performance on both individual and team levels.

\subsection{Virtualization level and work challenges}

Higher virtualization level is associated with more frequent work challenges. The virtualization level has a significant effect on work challenges for three conditions: Conflicts between team members $[\mathrm{F}(8,66)=1.92, \mathrm{p}<.05]$, Different cultures $[\mathrm{F}(8,66)=3.44, \mathrm{p}<.01]$ and Failure to work on a virtual basis $[\mathrm{F}(8,66)=2.92, \mathrm{p}<.01]$ (see Table 5 ). In other words, with a higher level of virtuality, respondents were more likely to experience conflicts in teams, find it more difficult to overcome cultural differences, and adapt to work virtually.

Table 5. ANOVA results using virtualization level as criterion

\begin{tabular}{|c|c|c|c|c|c|}
\hline Variables & $\begin{array}{l}\text { Sum of } \\
\text { Squares }\end{array}$ & df & $\begin{array}{l}\text { Mean } \\
\text { Square }\end{array}$ & $\mathrm{F}$ & $\mathrm{p}$ \\
\hline $\begin{array}{l}\text { 1. Lack of information } \\
\text { when working on a } \\
\text { common project }\end{array}$ & $\begin{array}{c}9.73 \\
82.94\end{array}$ & $\begin{array}{c}8 \\
66\end{array}$ & $\begin{array}{l}1.22 \\
1.26\end{array}$ & .97 & .47 \\
\hline 2. Lack of clear goal & $\begin{array}{l}12.21 \\
68.53\end{array}$ & $\begin{array}{c}8 \\
66\end{array}$ & $\begin{array}{l}1.53 \\
1.04\end{array}$ & 1.47 & .19 \\
\hline $\begin{array}{l}\text { 3. Conflicts between } \\
\text { team members }\end{array}$ & $\begin{array}{l}16.68 \\
39.99\end{array}$ & $\begin{array}{c}8 \\
66\end{array}$ & $\begin{array}{l}2.68 \\
1.40\end{array}$ & 1.92 & $.05^{\star}$ \\
\hline 4. Different cultures & $\begin{array}{l}17.09 \\
51.36\end{array}$ & $\begin{array}{c}8 \\
66\end{array}$ & $\begin{array}{c}2.09 \\
.61\end{array}$ & 3.44 & $.01^{\star *}$ \\
\hline $\begin{array}{l}\text { 5. Failure to work on } \\
\text { a virtual basis }\end{array}$ & $\begin{array}{l}21.06 \\
59.61\end{array}$ & $\begin{array}{c}8 \\
66\end{array}$ & $\begin{array}{c}2.63 \\
.90\end{array}$ & 2.92 & $.01^{\star *}$ \\
\hline $\begin{array}{l}\text { 6. Do not speak } \\
\text { foreign languages }\end{array}$ & $\begin{array}{c}4.32 \\
48.43\end{array}$ & $\begin{array}{c}8 \\
66\end{array}$ & $\begin{array}{l}.54 \\
.73\end{array}$ & .74 & .66 \\
\hline $\begin{array}{l}\text { 7. Time zone } \\
\text { differences }\end{array}$ & 26.62 & $\begin{array}{c}8 \\
66\end{array}$ & 3.33 & 1.93 & .07 \\
\hline
\end{tabular}

Virtualization level and performance. At the individual and team level, high degree of virtualization affects the effectiveness of the team (at the individual level, Satisfaction subscale $[\mathrm{F}(8,82)=2.16, \mathrm{p}<.05]$ and at the team level, Satisfaction subscale $[\mathrm{F}(1,26)=4.85, \mathrm{p}<.05])$, see Table 6 .

Table 6. ANOVA results using virtualization level as criterion

\begin{tabular}{|c|c|c|c|c|c|}
\hline $\begin{array}{c}\text { Variables } \\
\text { (INDIVIDUAL } \\
\text { LEVEL) }\end{array}$ & $\begin{array}{l}\text { Sum of } \\
\text { Squares }\end{array}$ & $\mathrm{df}$ & $\begin{array}{l}\text { Mean } \\
\text { Square }\end{array}$ & $\mathrm{F}$ & $\mathrm{p}$ \\
\hline $\begin{array}{l}\text { 1. Performance } \\
\text { subscale }\end{array}$ & $\begin{array}{c}5.76 \\
34.57\end{array}$ & $\begin{array}{c}8 \\
82\end{array}$ & $\begin{array}{l}.72 \\
.42\end{array}$ & 1.71 & .11 \\
\hline 2. Satisfaction subscale & $\begin{array}{c}8.61 \\
40.88\end{array}$ & $\begin{array}{c}8 \\
82\end{array}$ & $\begin{array}{l}1.08 \\
.50\end{array}$ & 2.16 & $.04^{\star}$ \\
\hline
\end{tabular}


End of Table 6

\begin{tabular}{|l|c|c|c|c|c|}
\hline \multicolumn{1}{|c|}{$\begin{array}{c}\text { Variables } \\
\text { (GROUP LEVEL) }\end{array}$} & $\begin{array}{c}\text { Sum of } \\
\text { Squares }\end{array}$ & $\mathrm{df}$ & $\begin{array}{c}\text { Mean } \\
\text { Square }\end{array}$ & $\mathrm{F}$ & $\mathrm{p}$ \\
\hline 1. Performance & .55 & 1 & .55 & 1.33 & .26 \\
subscale & 10.34 & 25 & .41 & & \\
\hline 2. Satisfaction subscale & 1.27 & 1 & 1.27 & 4.85 & $.04^{\star}$ \\
\hline
\end{tabular}

\section{Discussion and Conclusions}

The purpose of this study was to identify and explore the relationship between personality traits, work factors and team effectiveness within the context of IT teams.

Our study makes three important contributions. First, results of this study support the use of personality traits as predictors of team performance. Results indicate that personality traits are important to team effectiveness on the individual level as well. First hypothesis was partially confirmed. Individually expressed higher levels of Humility, Conscientiousness, and Openness to Experience positively relate to team Performance and Satisfaction.

Higher Performance subscale, which includes outcomes, quality, innovation, rate of progress, and other measures of success, positively correlates with Humility and Openness to Experience but relates negatively to Agreeableness.

Higher Satisfaction with their teamwork (including satisfaction with team cooperation, or member perception about their interactions and the degree of optimism for future cooperation) positively relates to Emotionality and Agreeableness.

According to the results, lower Extraversion and Emotionality are not related to team Performance and Satisfaction. There were no statistically significant differences between groups on the team level. According to the results, respondents with a more pronounced Honesty-Humility trait tend to assess their team Effectiveness more positively. A strong Honesty-Humility trait may lead to attentiveness and being strict to team Performance. Otherwise, Honesty-Humility appears to be an important personality trait in predicting job performance (Johnson et al., 2011). Conscientiousness correlates with team performance as well. Persons with high scores on the Conscientiousness scale strive for accuracy and perfection in all environments and work in a disciplined manner toward their goals. They embrace difficult tasks or challenging goals. This personal trait positively relates to team performance.

Positive relationships emerged between Agreeableness and the Satisfaction scale, however, Agreeableness negatively correlates with the Performance scale. Agreeable persons are naturally kind, have good relationships with others and are satisfied with their teamwork. Nevertheless, Agreeableness does not predict team effectiveness. This result contradicted earlier studies, which may be accounted for by the different tools used to evaluate personality traits or assess effectiveness (Wang \& Hsu, 2012; Norhanim, 2019). Team effectiveness is sensitive to task peculiarities (Gladstein, 1984) and in other studies it has been measured by performing different tasks (Santo, 2001; Norhanim, 2019). For example, people with lower levels of extraversion and higher levels of openness and conscientiousness tend to prefer online training and are more effective in virtual environments (Santo, 2001). The problem with such studies is that often they focus on the links between one specific personality trait and team effectiveness (Norhanim, 2019), ask respondents about their attitudes toward certain personality traits (i.e., whether they think a certain trait is beneficial to effectiveness) rather than use psychological methodology to assess team member traits themselves (Norhanim, 2019), or describe personality traits through managerial constructs (Chiu et al., 2016). Otherwise, personality traits may not be the main determinants of team effectiveness, so their relationship to performance is volatile.

Other results obtained do not contradict previous research. It is assumed that higher individual abilities lead to higher team performance (Magnusson et al., 2013; Solaja et al., 2016; Norhanim, 2019). The field of work determines which personality traits are important for operational efficiency (Driskell et al., 1987; McGrath, 1986). Limited research attention has been given to software developers' personality traits and their role to the team composition (Serban et al., 2015).

Second, the study results indicate that work challenges encountered by the respondents while working in an allocated team affect team performance. Lack of a clear purpose and inability to speak foreign languages have a significant effect on the Performance subscale. Lack of information when working on a common project, conflicts between team members, different cultures, and inability to speak foreign languages had a significant effect in team Satisfaction. On the team level, teams with the highest and lowest performance ratings exhibited statistically significant differences in lack of clear purpose in the Performance subscale and in the Satisfaction subscale means. According to the analysis, main disadvantages are issues in conceptual understanding (as lack of clear purpose or the lack of information), language barriers (team members do not speak foreign languages), and difficulties in resolving conflicts in virtual teams.

Communication through technology raises challenges. Working in multiple locations and in different countries with varied time zones complicates team communication. In order to assess temporal discontinuity, such as time zone differences, they have to work extended days or collaborate with people in different time zones in order to communicate with remote team members (Chudoba et al., 2005). The obtained results are similar to data reported by other authors - cultural and work process diversity negatively impact performance (Chudoba et al., 2005). Work predictability and smooth communication with non-team members can mitigate the consequences (Chudoba et al., 2005). And, on the contrary, lack of information when working on a common project (Collins et al., 2014), lack 
of clear team goals (Collins et al., 2014) and different cultures (Henry \& Hartzler, 1998), may negatively impact performance.

Third, a higher virtualization level is associated with more frequent work challenges and negatively affects performance. High degree of virtualization negatively relates to three work challenges - Conflicts between team members, Different cultures, and Failure to work on a virtual basis. The results of this study support that higher virtualization level is associated with more frequent work challenges in IT teams due to differences between colleagues from various cultures, difficulties in speaking a foreign language, and time zones. This coincides with the results of other surveys which show it to be harder to work in a virtual environment (Collins et al., 2014; Henry \& Hartzler, 1998; Martins \& Schilpzand, 2011). However, most previous research is devoted to temporal virtualization (Gasson \& Waters, 2013; Yilmaz \& Peña, 2014), analyzed in theoretical articles (Engle et al., 2015), or conducted on a student sample (Yilmaz \& Peña, 2014).

At the individual and team levels, high degree of virtualization affects the effectiveness of the team - Satisfaction with the team decreases. Frequent, spontaneous communication reduces the likelihood of conflicts, facilitates coordination, improves teamwork and creates a sense of community in a team (Magnusson et al., 2013). Remote communication and lack of direct communication make it difficult to cooperate effectively (Collins et al., 2014; Jiang et al., 2014). Other studies confirm that team distribution, workplace mobility, and variety of work practices indirectly affect team performance (Chudoba et al., 2005).

In conclusion, study results demonstrate that certain personality traits, such as higher humility, conscientiousness, and openness to experience, positively relate to higher team performance and satisfaction, while work factors, such as lack of a clear purpose and inability to speak foreign languages, are a significant main effect for the Performance subscale. Lack of information when working on a common project, conflicts between team members, different cultures, and inability to speak foreign languages have a significant positive effect in team Satisfaction. Higher virtualization level is associated with more frequent work challenges in IT teams due to differences between colleagues from various cultures, difficulties in speaking a foreign language, and time zones. It is also associated with more frequent work challenges and negatively affect performance.

Considering the theoretical significance of the study, researchers analyze the importance of factors for team effectiveness regardless of context - such as organizational (as virtualization level, work factors) and psychological factors (as personality traits). However, previous research in team effectiveness confirm, that some positive correlations (between personality traits of IT project managers and project success (Creasy \& Anantatmula, 2013) can be seen as prerequisites for team effectiveness in IT organization. It is likely that organizational factors such as the degree of virtualization level can change frequency of work challenges and team effectiveness in IT team. Software development teams' effectiveness has not been sufficiently researched so far, and therefore researchers lack information on team effectiveness from a psychological perspective (Kayworth \& Leidner, 2001-2002).

The study has practical implications. IT sector has difficulties in organizing work process - high staff turnover, difficulties in implementing IT projects on time (Avritzer et al., 2010; Casey \& Richardson, 2008, 2009; Milewski et al., 2008 by Colomo-Palacios et al., 2014). IT teams are still looking for individual solutions, although the challenges are common to the entire IT sector. Selection or staff- assessment focuses on technical, organizational competencies because it is not clear what competencies or psychological characteristics are important to an effective IT team (Gibson \& Cohen, 2003). For software engineers, our study shows that personality traits can increase team effectiveness. Therefore, putting more effort into the recruitment process and assessing personality traits have important implications for software engineer team effectiveness. Practitioners would benefit taking into account and reducing negative work factors in a virtual team. Our findings supplement organizational literature based on etic observations of the effectiveness of virtual work and provide a basis for further theorizations on how team effectiveness is affected by personality traits and work factors.

\section{Limitations and future research}

There are limitations to this study that should be acknowledged. First off, small sample size and self-reported data are its major limitations. Further research is needed to confirm the current assumptions. Common method variance, and cross-sectional design may be an additional threat to the validity of this study. Moving forward, researchers should incorporate longitudinal designs to understand the complex nature of team dynamics.

Future research should also extend findings by examining a higher number of variables. A larger amount of data would be significant in a more complex statistical analysis implementation. On the team level, some characteristics (e.g., personality traits) should be explored to establish whether they are important as homogeneous (the same personality traits for all team members) or heterogeneous (different from other team members) traits that lead to effective performance.

The study was focused on the performance of software developers, where the respondents assessed the effectiveness of their activities themselves. However, other stakeholders (e.g., leaders, clients, or project managers) may hold alternative views about team effectiveness. In future studies, self-reported data may be supplemented by colleagues' assessments or gained as objective data.

According to Raghuram and colleagues (2019), virtual work research is at a stage where some form of 
interdisciplinary overlap still exists, and scholars might be open to ideas emerging from other research areas. On the other hand, due to research conducted in different fields of science, it remains difficult to combine the knowledge accumulated by researchers and compare the obtained results.

In future research, virtual work could be treated as a complement to traditional teamwork rather than its alternative. According to Pettersen (2020), virtual work will not replace traditional teamwork but will build on and possibly strengthen it through communication and social relationships that may expand into virtual spaces. The changes in the labor market in recent years only prove the relevance of the topic and raise questions for future research.

\section{Disclosure statement}

The authors are not aware of any competing financial, professional, or personal interests from other parties.

\section{References}

Allport, G. W., Cattell, R. B., \& Eysenck, H. J. (2003). The trait perspective. In An introduction to theories of personality (pp. 257). Lawrence Erlbaum Associates, NJ.

Ashton, M. C., \& Lee, K. (2009). The HEXACO-60: A short measure of the major dimensions of personality. Journal of Personality Assessment, 91(4), 340-345. https://doi.org/10.1080/00223890902935878

Avritzer, A., Paulish, D., Cai, Y., \& Sethi, K. (2010). Coordination implications of software architecture in a global software development project. Journal of Systems and Software, 83(10), 1881-1895. https://doi.org/10.1016/j.jss.2010.05.070

Axtell, C. M., Fleck, S. J., \& Turner, N. (2004). Virtual team: collaborating across distance. In C. L. Cooper \& I. T. Robertson (Eds.), International review of industrial and organizational psychology. Wiley, Chichester.

Balthazard, P., Potter, R. E., \& Warren, J. (2004). Expertise, extraversion and group interaction styles as performance indicators in virtual teams. Database for Advances in Information Systems, 35(1), 41-64. https://doi.org/10.1145/968464.968469

Barrick, M. R., \& Mount, M. K. (1991). The Big Five personality dimensions and job performance: a meta-analysis. Personnel Psychology, 44(1), 1-26.

https://doi.org/10.1111/j.1744-6570.1991.tb00688.x

Barry, B., \& Stewart, G. L. (1997). Composition, process and performance in self-managed groups: the role of personality. Journal of Applied Psychology, 82(1), 62-78. https://doi.org/10.1037/0021-9010.82.1.62

Bógdał-Brzezińska, A. (2020). Information and Communication Technology (ICT) as a source of development of states and regions in the age of globalization. Journal of Geography, Politics and Society, 10(1), 15-22.

https://doi.org/10.26881/jpgs.2020.1.03

Brown, H. G., Scott Poole, M., \& Rodgers, T. L. (2004). Interpersonal traits, complementarity, and trust in virtual collaboration. Journal of Management Information Systems, 20(4), 115-137. https://doi.org/10.1080/07421222.2004.11045785

Brownell, J. (2006). Meeting the competency needs of global leaders: a partnership approach. Human Resource Management, 45(3), 3. https://doi.org/10.1002/hrm.20115
Bruck, C. S., \& Allen, T. D. (2003). The relationship between big five personality traits, negative affectivity, type A behavior, and work-family conflict. Journal of Vocational Behavior, 63(3), 457-472. https://doi.org/10.1016/S0001-8791(02)00040-4

Casey, V., \& Richardson, I. (2008). Virtual teams: understanding the impact of fear. Software Process: Improvement and Practice, 13(6), 511-526. https://doi.org/10.1002/spip.404

Casey, V., \& Richardson, I. (2009). Implementation of global software development: a structured approach. Software Process Improvement and Practice, 14(5), 247-267. https://doi.org/10.1002/spip.422

Carmel, E., \& Agarwal, R. (2001). Tactical approaches for alleviating distance in global software development. IEEE Software, 18(2), 22-29. https://doi.org/10.1109/52.914734

Chatzipetrou, P., Angelis, L., Barney, S., \& Wohlin, C. (2015). An experience-based framework for evaluating alignment of software quality goals. Software Quality Journal, 23(4), 567-594. https://doi.org/10.1007/s11219-014-9251-5

Chiu, C. Y. C., Owens, B. P., \& Tesluk, P. E. (2016). Initiating and utilizing shared leadership in teams: The role of leader humility, team proactive personality, and team performance capability. Journal of Applied Psychology, 101(12), 1705. https://doi.org/10.1037/apl0000159

Chudoba, K. M., Wynn, E., Lu, M., \& Watson-Manheim, M. B. (2005). How virtual are we? Measuring virtuality and understanding its impact on a global organization. Information Systems Journal, 15, 279-306.

https://doi.org/10.1111/j.1365-2575.2005.00200.x

Chujfi, S., \& Meinel, C. (2015). Patterns to explore cognitive preferences and potential collective intelligence empathy for processing knowledge in virtual settings. Journal of Interaction Science, 3(1), 5. https://doi.org/10.1186/s40166-015-0006-y

Collins, N., Chou, Y., \& Warner, M. (2014). Member satisfaction, communication and role of leader in virtual self-managed teamwork: Case studies in Asia-Pacic region. Human Systems Management, 33(4), 155-170. https://doi.org/10.3233/HSM-140824

Colomo-Palacios, R., Casado-Lumbreras, C., Soto-Acosta, P., García-Peñalvo, F. J., \& Tovar, E. (2014). Project managers in global software development teams: a study of the effects on productivity and performance. Software Quality Journal, 22(1), 3-19. https://doi.org/10.1007/s11219-012-9191-x

Constant, D., Sproull, L., \& Kiesler, S. (1996). The kindness of strangers: the usefulness of electronic weak ties for technical advice. Organization Science, 7(2), 119-135. https://doi.org/10.1287/orsc.7.2.119

Creasy, T., \& Anantatmula, V. (2013). From every direction: How personality traits and dimensions of project managers can conceptually affect project success. Project Management Journal, 44(6), 36-51. https://doi.org/10.1002/pmj.21372

Cruz, S., da Silva, F. Q., \& Capretz, L. F. (2015). Forty years of research on personality in software engineering: A mapping study. Computers in Human Behavior, 46, 94-113. https://doi.org/10.1016/j.chb.2014.12.008

Dennis, A. R., \& Wixom, B. H. (2001-2002). Investigating the moderators of the group support system use with metaanalysis. Journal of Management Information Systems, 18(3), 235-257. https://doi.org/10.1080/07421222.2002.11045696

Denison, D. R., Hart, S. L., \& Kahn, J. A. (1996). From chimneys to cross-functional teams: Developing and validating a diagnostic model. Academy of Management Journal, 39(4), 1005-1023. https://doi.org/10.2307/256721

Dingsøyr, T., \& Dybå, T. (2012). Team effectiveness in software development: Human and cooperative aspects in team 
effectiveness models and priorities for future studies. In 2012 5th International workshop on co-operative and human aspects of software engineering (pp. 27-29). IEEE.

https://doi.org/10.1109/CHASE.2012.6223016

De Vreede, T., de Vreede, G. J., Ashley, G., \& Reiter-Palmon, R. (2012). Exploring the effects of personality on collaboration technology transition. In 45th Hawaii International Conference on System Sciences (pp. 869-878). IEEE.

https://doi.org/10.1109/HICSS.2012.269

Devaraj, S., Easley, R. F., \& Crant, J. M. (2008). How does personality matter? Relating the five-factor model to technology acceptance and use. Information Systems Research, 19(1), 93-105. https://doi.org/10.1287/isre.1070.0153

Digman, J. M., \& Inouye, J. (1986). Further specification of the five robust factors of personality. Annual Review of Psychology, 50(1), 116-123. https://doi.org/10.1037/0022-3514.50.1.116

Dineen, B. R. (2005). TeamXchange: A team project experience involving virtual teams and fluid team membership. Journal of Management Education, 29(4), 593-616. https://doi.org/10.1177/1052562905276275

Dobre, C., \& Xhafa, F. (2014). Intelligent services for big data science. Future Generation Computer Systems, 37, 267-281. https://doi.org/10.1016/j.future.2013.07.014

Driskell, J. E., Hogan, R., \& Salas, E. (1987). Personality and group performance. In C. Hendrick (Ed.), Personality and Social Psychology Review, 91-112.

Eissa, G., Fox, C., Webster, B. D., \& Kim, J. (2012). A framework for leader effectiveness in virtual teams. Journal of Leadership, Accountability and Ethics, 9(2), 11-22.

El-Sofany, H., Alwadani, H., \& Alwadani, A. (2014). Managing virtual team work in IT projects: survey. International Journal of Advanced Corporate Learning, 7(4).

https://doi.org/10.3991/ijac.v7i4.4018

Engle, Sr, A. D., Festing, M., \& Dowling, P. J. (2015). Gaining altitude on global performance management processes: a multilevel analysis. The International Journal of Human Resource Management, 26(15), 1955-1964.

https://doi.org/10.1080/09585192.2015.1041761

Ewen, C., Wihler, A., Blickle, G., Oerder, K., Ellen, B. P., III, Douglas, C., et al. (2013). Further specification of the leader political skill-leadership effectiveness relationships: Transformational and transactional leader behavior as mediators. The Leadership Quarterly, 24(4), 516-533.

https://doi.org/10.1016/j.leaqua.2013.03.006

Felker, J. A. (2012). EU's new member states: an untapped (and underappreciated) source of talent for MNCs? The International Journal of Human Resource Management, 23(2), 255-277. https://doi.org/10.1080/09585192.2011.606112

Furumo, K., de Pillis, E., \& Green, D. (2009). Personality influences trust differently in virtual and face-to-face teams. International Journal of Human Resources Development and Management, 9(1), 36. https://doi.org/10.1504/IJHRDM.2009.021554

García-Crespo, Á., Colomo-Palacios, R., Soto-Acosta, P., \& Ruano-Mayoral, M. (2010). A qualitative study of hard decision making in managing global software development teams. Information Systems Management, 27(3), 247-252. https://doi.org/10.1080/10580530.2010.493839

Gassmann, O., \& Von Zedtwitz, M. (2003). Trends and determinants of managing virtual $\mathrm{R} \& \mathrm{D}$ teams. $R \& D$ Management, 33(3), 243-262. https://doi.org/10.1111/1467-9310.00296

Gasson, S., \& Waters, J. (2013). Using a grounded theory approach to study online collaboration behaviors. European Journal of Information Systems, 22(1), 95-118.

https://doi.org/10.1057/ejis.2011.24
Gibson, C. B., \& Cohen, S. G. (2003). The last word: Conclusions and implication. In C. B. Gibson \& S. G. Cohen (Eds.), Virtual teams that work: Creating conditions for virtual team effectiveness (pp. 403-421). Jossey-Bass.

Gibson, C. B., \& Gibbs, J. L. (2006). Unpacking the concept of virtuality: The effects of geographic dispersion, electronic dependence, dynamic structure, and national diversity on team innovation. Administrative Science Quarterly, 51(3), 451-495. https://doi.org/10.2189/asqu.51.3.451

Gladstein, D. L. (1984). Groups in context: A model of task group effectiveness. Administrative Science Quarterly, 29(4), 499-517. https://doi.org/10.2307/2392936

Graziano, W. G., Jackson-Campbell, L. A., \& Hair, E. C. (1996). Perceiving interpersonal conflict and reacting to it: the case for agreeableness. Journal of Personality and Social Psychology, 70(4), 820-835. https://doi.org/10.1037/0022-3514.70.4.820

Grenier, R., \& Metes, G. (1995). Going virtual: moving your organization in the 21st century. Prentice Hall.

Hackman, J. R., \& Oldham, G. R. (1980). Work redesign. Addison-Wesley.

Henry, J., \& Hartzler, M. (1998). Tools for virtual teams: a team fitness companion. American Society for Quality Press. https://doi.org/10.1097/01445442-199809000-00012

Hertel, G., Geister, S., \& Konradt, U. (2005). Managing virtual teams: A review of current empirical research. Human Resource Management Review, 15(1), 69-95. https://doi. org/10.1016/j.hrmr.2005.01.002

Higgs, M., \& Dulewicz, V. (2016). Developments in leadership thinking. In Leading with Emotional Intelligence (pp. 75-103). Palgrave Macmillan, Cham. https://doi.org/10.1007/978-3-319-32637-5_6

Hinds, P. J., \& Mortensen, M. (2005). Understanding conflict in geographically distributed teams: The moderating effects of shared identity, shared context, and spontaneous communication. Organization Science, 16(3), 290-307. https://doi.org/10.1287/orsc.1050.0122

Hoegl, M., \& Gemuenden, H. G. (2001). Teamwork quality and the success of innovative projects: A theoretical concept and empirical evidence. Organization Science, 12(4), 435-449. https://doi.org/10.1287/orsc.12.4.435.10635

Hogan, R., Curphy, G. J., \& Hogan, J. (1994). What we know about leadership: effectiveness and personality. American Psychologist, 49(6), 485-504. https://doi.org/10.1037/0003-066X.49.6.493

Horwitz, F. M., Heng, C. T., \& Quazi, H. A. (2003). Finders, keepers? Attracting, motivating and retaining knowledge workers. Human Resource Management Journal, 13(4), 23-44. https://doi.org/10.1111/j.1748-8583.2003.tb00103.x

Hsu, M. H., Chen, I. Y. L., Chiu, C. M., \& Ju, T. L. (2007). Exploring the antecedents of team performance in collaborative learning of computer software. Computers \& Education, 48(4), 700-718. https://doi.org/10.1016/j.compedu.2005.04.018

Huang, M. P., Chi, S. C., \& Huang, K. L. (2002). Team structure and effectiveness in cross-functional teams: a structural contingency perspective. Journal of Management, 19(6), 9791007.

Ion, A., Iliescu, D., Aldhafri, S., Rana, N., Ratanadilok, K., Widyanti, A., \& Nedelcea, C. (2017). A cross-cultural analysis of personality structure through the lens of the HEXACO model. Journal of Personality Assessment, 99(1), 25-34. https://doi.org/10.1080/00223891.2016.1187155

Jarvenpaa, S. L., Knoll, K., \& Leidner, D. E. (1998). Is anybody out there? Antecedents of trust in global virtual teams. Journal of Management Information Systems, 14(4), 26-64. https://doi.org/10.1080/07421222.1998.11518185 
Jacques, P. H., Garger, J., Brown, C. A., \& Deale, C. S. (2009). Personality and virtual reality team candidates: The roles of personality traits, technology anxiety and trust as predictors of perceptions of virtual reality teams. Journal of Business and Management, 15(2), 143-158.

Jehn, K. A. (1995). A multimethod examination of the benefits and detriments of intragroup conflict. Administrative Science Quarterly, 40(2), 256-282. https://doi.org/10.2307/2393638

Jehn, K. A. (1997). Qualitative analysis of conflict types and dimensions in organizational groups. Administrative Science Quarterly, 42(3), 530-557. https://doi.org/10.2307/2393737

Jiang, J. J., Chang, J. Y., Chen, H. G., Wang, E. T., \& Klein, G. (2014). Achieving IT program goals with integrative conflict management. Journal of Management Information Systems, 31(1), 79-106. https://doi.org/10.2753/MIS0742-1222310104

Joinson, C. (2002). Managing virtual teams. HR Magazine, 47, 68-69.

Johnson, M. K., Rowatt, W. C., \& Petrini, L. (2011). A new trait on the market: Honesty-Humility as a unique predictor of job performance ratings. Personality and Individual Differences, 50(6), 857-862. https://doi.org/10.1016/j.paid.2011.01.011

Jokūbauskienè, S. (2013). Informacijos ir komunikacijos specialistų strateginès lyderystès kompetencijų formavimo tendencijos žinių visuomenèje. Informacijos mokslai, 64, 90-112. https://doi.org/10.15388/Im.2013.0.1598

Judge, T. A., Higgins, C. A., Thoresen, C. J., \& Barrick, M. R. (1999). The big five personality traits, general mental ability, and career success across the life span. Personnel Psychology, 52(3), 621-652.

https://doi.org/10.1111/j.1744-6570.1999.tb00174.x

Kayworth, T. R., \& Leidner, D. E. (2001-2002). Leadership effectiveness in global virtual teams. Journal of Management Information Systems, 18(3), 7-40. https://doi.org/10.1080/07421222.2002.11045697

Kirkman, B. L., Rosen, B., et al. (2002). Five challenges to virtual team success: lessons from Sabre, Inc. Academy of Management Executive, 16(3), 67-79.

https://doi.org/10.5465/ame.2002.8540322

Kommeren, R., \& Parviainen, P. (2007). Philips experiences in global distributed software development. Empirical Software Engineering, 12(6), 647-660.

https://doi.org/10.1007/s10664-007-9047-3

Lankes, D., Shachaf, P., Hara, N., Meho, L., Kwon, N., Li, B., \& Sakai, Y. (2005). Cross-cultural analysis of virtual reference. Proceedings of the American Society for Information Science and Technology, 42(1).

https://doi.org/10.1002/meet.1450420169

Lazzarotti, V., Manzini, R., \& Pellegrini, L. (2015). Is your openinnovation successful? The mediating role of a firm's organizational and social context. The International Journal of $\mathrm{Hu}$ man Resource Management, 26(19), 2453-2485.

https://doi.org/10.1080/09585192.2014.1003080

Lee, K., Ashton, M. C., \& de Vries, R. E. (2005). Predicting workplace delinquency and integrity with the HEXACO and fivefactor models of personality structure. Human Performance, 18(2), 179-197. https://doi.org/10.1207/s15327043hup1802_4

Li, W., Liu, K., Belitski, M., Ghobadian, A., \& O’Regan, N. (2016). e-Leadership through strategic alignment: An empirical study of small-and medium-sized enterprises in the digital age. Journal of Information Technology, 31(2), 185-206. https://doi.org/10.1057/jit.2016.10

Lipnack, J., \& Stamps, J. (1997). Virtual teams: reaching across space, time, and organizations with technology. John Wiley \& Sons, Inc.
May, A., \& Carter, C. (2001). A case study of virtual team working in the European automotive industry. International Journal of Industrial Ergonomics, 27(3), 171-186.

https://doi.org/10.1016/S0169-8141(00)00048-2

McGrath, J. E. (1986). Studying groups at work: Ten critical needs for theory and practice. Designing Effective Work Groups, 362, 391.

Magnusson, P., Westjohn, S. A., Semenov, A. V., Randrianasolo, A. A., \& Zdravkovic, S. (2013). The role of cultural intelligence in marketing adaptation and export performance. Journal of Marketing Research, 21(4), 44-61. https://doi.org/10.1509/jim.13.0055

Martins, L. L., \& Schilpzand, M. C. (2011). Global virtual teams: Key developments, research gaps, and future directions. In Research in personnel and human resources management (pp. 1-72). Emerald Group Publishing Limited. https://doi.org/10.1108/S0742-7301(2011)0000030003

Miles, R. E., \& Snow, C. C. (1986). Organizations: new concepts for new forms. California Management Review, 28(3), 62-73. https://doi.org/10.2307/41165202

Miles, R. E., \& Snow, C. C. (1992). Causes of failure in network organizations. California Management Review, 34(4), 53-72. https://doi.org/10.2307/41166703

Matzler, K., Mooradian, T., \& Renzl, B. (2006). Who trusts? Personality, trust and knowledge sharing. Management Learning, 37(4), 523-540. https://doi.org/10.1177/1350507606073424

Maznevski, M. L., \& Chudoba, K. M. (2000). Bridging space over time: Global virtual team dynamics and effectiveness. Organization Science, 11(5), 473-492. https://doi.org/10.1287/orsc.11.5.473.15200

McDonough, E., Kahn, K., \& Barczak, G. (2001). An investigation of the use of global, virtual, and collocated new product development teams. The Journal of Product Innovation Management, 18(2), 110-120.

https://doi.org/10.1111/1540-5885.1820110

Moe, N. B., \& Dingsøyr, T. (2008). Scrum and team effectiveness: Theory and practice. In International Conference on Agile Processes and Extreme Programming in Software Engineering (pp. 11-20). Springer. https://doi.org/10.1007/978-3-540-68255-4_2

Naik, Y. N., \& Bisht, M. (2014). Structural equation model for effectiveness of technical managers in information technology industry. International Journal of Supply Chain Management, 3(3). https://ojs.excelingtech.co.uk/index.php/IJSCM/article/ viewFile/974/pdf

Nguyen-Duc, A., Cruzes, D. S., \& Conradi, R. (2015). The impact of global dispersion on coordination, team performance and software quality - A systematic literature review. Information and Software Technology, 57, 277-294.

https://doi.org/10.1016/j.infsof.2014.06.002

Niederman, F., \& Beise, C. M. (1999). Defining the virtualness of groups, teams, and meetings. In Papers presented at SIGCPR'99 ACM (pp. 14-18). New Orleans Louisiana. https://doi.org/10.1145/299513.299606

Noll, J., Beecham, S., \& Richardson, I. (2010). Global software development and collaboration: Barriers and solutions. ACM Inroads, 1(3), 66-78. https://doi.org/10.1145/1835428.1835445

Norhanim, Z. (2019). The impact of virtual team characteristics on project effectiveness. Journal of Design+ Built, 12(1).

Nurmi, N., \& Hinds, P. J. (2016). Job complexity and learning opportunities: A silver lining in the design of global virtual work. Journal of International Business Studies, 47(6), 631-654. https://doi.org/10.1057/jibs.2016.11

O’Neill, T. A., Hambley, L. A., \& Bercovich, A. (2014). Prediction of cyberslacking when employees are working away from the 
office. Computers in Human Behavior, 34, 291-298. https://doi.org/10.1016/j.chb.2014.02.015

Owens, B. P., Johnson, M. D., \& Mitchell, T. R. (2013). Expressed humility in organizations: Implications for performance, teams, and leadership. Organization Science, 24(5), 1517-1538. https://doi.org/10.1287/orsc.1120.0795

Owens, B. P., Rowatt, W. C., \& Wilkins, A. L. (2011). Exploring the relevance and implications of humility in organizations. In The Oxford Handbook of positive organizational scholarship (pp. 260-272). Oxford Library of Psychology. https://doi.org/10.1093/oxfordhb/9780199734610.013.0020

Paik, Y., Vance, C. M., \& Stage, H. D. (2000). A test of assumed cluster homogeneity for performance appraisal management in South East Asian countries. International Journal of $\mathrm{Hu}$ man Resource Management, 11(4), 736-750.

https://doi.org/10.1080/09585190050075097

Pettersen, L. (2020). The role of offline places for communication and social interaction in online and virtual spaces in the multinational workplace. Nordicom Review, 37(s1), 131-146. https://doi.org/10.1515/nor-2016-0028

Raghuram, S., Hill, N. S., Gibbs, J. L., \& Maruping, L. M. (2019). Virtual work: bridging research clusters. Academy of Management Annals, 13(1), 308-341.

https://doi.org/10.5465/annals.2017.0020

Salas, E., Sims, D. E., \& Burke, C. S. (2005). Is there a "big five" in teamwork? Small Group Research, 36(5), 555-599. https://doi.org/10.1177/1046496405277134

Santo, S. A. (2001). Virtual learning, personality, and learning styles [PhD Thesis, University of Virginia]. Charlottesville, VA, USA, Volume 62(1-A).

Serban, A., Yammarino, F. J., Dionne, S. D., Kahai, S. S., Hao, C., McHugh, K. A., \& Peterson, D. R. (2015). Leadership emergence in co-located and virtual teams: A multilevel model with agent-based simulations, quasi-experimental and experimental tests. The Leadership Quarterly, 26(3), 402-418. https://doi.org/10.1016/j.leaqua.2015.02.006

Simons, T. L., \& Peterson, R. S. (2000). Task conflict and relationship conflict in top management teams: the pivotal role of intragroup trust. Journal of Applied Psychology, 85(1), 1-10. https://doi.org/10.1037/0021-9010.85.1.102

Shachaf, P., \& Hara, N. (2002). Ecological approach to virtual team effectiveness. In Proceedings of Americas Conference on Information Systems, 8, 1814-1819.

Shea, G. P., \& Guzzo R. A. (1987). Groups as human resources. Research in Personnel and Human Resources Management, 5, 323-356.

Smite, D., Wohlin, C., Gorschek, T., \& Feldt, R. (2010). Empirical evidence in global software engineering: A systematic review. Empirical Software Engineering, 15(1), 91-118. https://doi.org/10.1007/s10664-009-9123-y

Sundstrom, E., De Muese, K. P., \& Futrell, D. (1990). Work teams: applications and effectiveness. The American Psychologist, 45(2), 120-133. https://doi.org/10.1037/0003-066X.45.2.120

Solaja, M. O., Idowu, E. F., \& James, E. A. (2016). Exploring the relationship between leadership communication style, personality trait and organizational productivity. Serbian Journal of Management, 11(1), 99-117.

https://doi.org/10.5937/sjm11-8480

Sooraj, P., \& Mohapatra, P. K. J. (2008). Modeling the 24-h software development process. Strategic Outsourcing: An International Journal, 1(2), 122-141.

https://doi.org/10.1108/17538290810897147

Stelmokienè, A. (2012). Pavaldinių požiūris i vadovavimo efektyvumą: asmenybès bruožų, socialinio suvokimo charakteristiku ir vertinimo sąlygu svarba [Doctoral dissertation, Vytautas Magnus University]. Lithuania.

Thuong, N. U. (2019). Virtual teams in the digital age. Hue University Journal of Science: Economics and Development, 128(5C), 67-80.

https://doi.org/10.26459/hueuni-jed.v128i5C.5121

Tjosvold, D. (1988). Cooperative and competitive interdependence: Collaboration between departments to serve customers. Group \& Organization Studies, 13, 274-289. https://doi.org/10.1177/105960118801300303

Verburg, R. M., Bosch-Sijtsema, P., \& Vartiainen, M. (2013). Getting it done: Critical success factors for project managers in virtual work settings. International Journal of Project Management, 31(1), 68-79.

https://doi.org/10.1016/j.ijproman.2012.04.005

Wang, M. L. (2010, July). A study of team effectiveness influenced by the fitting between team personality composition and team virtualization level. In PICMET 2010 technology management for global economic growth (pp. 1-8). IEEE.

Wang, M. L., \& Hsu, B. F. (2012). A study to explore the team virtualization level and team effectiveness from the team personality composition. Journal of the Knowledge Economy, 3(2), 199-216. https://doi.org/10.1007/s13132-011-0079-y

Weick, K. E. (2001). Leadership as the legitimation of doubt. In W. Bennis, G. M. Spreitzer, \& T. G. Cummings (Eds.), The future of leadership: Today's top leadership thinkers speak to tomorrow's leaders. Jossey-Bass.

Webster, J., \& Randle, K. (2016). Virtual workers and the global labour market. Palgrave Macmillan.

https://doi.org/10.1057/978-1-137-47919-8

White, K. (1984). MIS project teams: An investigation of cognitive style implications. MIS Quarterly, 8(2), 95-101. https://doi.org/10.2307/249346

Zakaria, N., Amelinck, A., \& Wilemon, D. (2004). Working together apart? Building a knowledge-sharing culture for global virtual teams. Creativity and Innovation Management, 13(1), 15-29. https://doi.org/10.1111/j.1467-8691.2004.00290.x

Xiang, C., Lu, Y., \& Gupta, S. (2013). Knowledge sharing in information system development teams: examining the impact of shared mental model from a social capital theory perspective. Behaviour \& Information Technology, 32(10), 1024-1040. https://doi.org/10.1080/0144929X.2012.745901

Yilmaz, G., \& Peña, J. (2014). The influence of social categories and interpersonal behaviors on future intentions and attitudes to form subgroups in virtual teams. Communication Research, 41(3), 333-352. https://doi.org/10.1177/0093650212443696 